\title{
ГАРМОНІЗАЦІЯ ЗАКОНОДАВСТВА УКРАЇНИ \\ ТА СВРОПЕЙСЬКОГО СОЮЗУ У СФЕРІ НАКАЗНОГО ПРОВАДЖЕННЯ В ЦИВІЛЬНОМУ ПРОЦЕСІ
}

Великорода О. М.

\section{ВСТУП}

Сьогодні в Україні відбувається активне реформування судової системи, спрямоване на забезпечення основних демократичних стандартів під час здійснення правосуддя. Варто підкреслити, що основне завдання законодавця у сфері врегулювання відносин із вирішення цивільних справ полягає в забезпеченні доступності, швидкості й ефективності судового розгляду. Саме на виконання даного завдання і спрямований інститут наказного провадження, який, хоча і з'явився тільки в Цивільному процесуальному кодексі України (далі - ЦПК України), ухваленому 18 березня 2004 р., уже сьогодні довів ефективність запровадження. Так, у 2018 р. в порядку наказного провадження розглянуто 152433 справи, що становить 19,75\% від загальної кількості справ, що розглядалися в порядку цивільного судочинства. 91,89\% заяв про видачу судового наказу було задоволено і тільки $3,70 \%$ судових наказів було скасовано ${ }^{1}$. Такі дані судової статистики дозволяють зробити висновок про високу ефективність наказного провадження в цивільному процесі України.

Аналіз наказного провадження в законодавстві країн Європейського Союзу дозволяє виділити дві основні моделі правового регулювання: а) доказову модель (Франція, Бельгія, Італія, Іспанія), яка передбачає, що заявник зобов'язаний надати суду письмові докази, на яких грунтуються його вимоги; суд зобов'язаний розглянути подані докази, за їхньої обгрунтованості видати судовий наказ; б) бездоказову модель (Німеччина, Фінляндія, Швеція), яка передбачає, що суд не розглядає обгрунтованість вимог заявника, якщо заява відповідає формальним вимогам, суд видає судовий наказ; у даній моделі процесуальний тягар покладається на боржника, своєчасне реагування якого блокує виконання судового наказуㄹ․ У подальшому доцільним $\epsilon$ аналіз наказного провадження

\footnotetext{
1 Форма № 1-ц. Звіт судів першої інстанції про розгляд справ у порядку цивільного судочинства за 2018 p. URL: https://court.gov.ua/userfiles/media/media/1c_2018.xlsx (дата звернення: 13.02.2020).

2 Крымский Д. Упрощенные производства в гражданском процессе зарубежных стран : автореф. дис. ... канд. юрид. наук: 12.00.15. Москва, 2011. С. 21-22.
} 
в законодавствах саме Франції та Німеччині, які є еталонами різних моделей правового регулювання даного інституту.

Окремо вартозвернути увагуна наявність Регламенту Свропейського парламенту та Ради Європейського Союзу № 1896/2006 від 12 грудня 2006 р. «Про введення Свропейського наказного провадження», який ухвалений із метою спрощення і прискорення судового розгляду та зменшення судових витрат під час розгляду транскордонних цивільних і комерційних справ. Даний правовий акт став базовим для багатьох країн Свропейського Союзу під час визначення напрямів розвитку даного інституту.

У зв'язку з активним реформуванням українського законодавства у сфері здійснення судочинства, яке відбувається сьогодні, виникає необхідність порівняння правового регулювання наказного провадження в Європейському Союзі й Україні для визначення основних шляхів удосконалення вітчизняного законодавства.

\section{1. Вимоги, за яких може бути видано судовий наказ}

Аналізуючи підхід європейського законодавця до питання про коло справ, які вирішуються в порядку наказного провадження, варто зазначити, що, на відміну від українського законодавства, де чітко передбачено категорії справ, за якими може видаватися судовий наказ, у ст. 2 Регламенту «Про введення Європейського наказного провадження» вказуються категорії справ, до яких не може застосовуватись наказне провадження, зокрема у справах щодо: а) права власності, яке виникає 3 відносин подружжя, заповіту чи правонаступництва; б) банкрутства, судового розгляду щодо неплатоспроможних компаній чи інших юридичних осіб, медіаційних процедур, мирових угод чи аналогічних процесуальних дій; в) соціального забезпечення; г) недоговірних зобов'язань, за винятком випадків, коли зобов'язання складали предмет домовленості сторін або якщо був визнаний борг однією зі сторін, а також якщо зобов'язання стосуються погашених боргів, що виникли зі спільного володіння майном. Окрім цього, положення вищеназваного Регламенту не поширюються на відносини в податковій, митній і адміністративній сферах, а також щодо відповідальності держав за дії чи бездіяльність під час здійснення державної влади ${ }^{3}$.

\footnotetext{
3 Regulation (EC) № 1896/2006 of the European Parliament and of the Council of 12 December 2006 creating a European order for payment procedure. URL: http://eur-lex.europa.eu/legalcontent/EN/TXT/?uri=celex:32006R1896 (дата звернення: 13.02.2020).
} 
У цивільно-процесуальному законодавстві Франції інститут наказного провадження (procédures d'injonction) передбачає три процедури: наказ про сплату (injonction de payer); європейський наказ про сплату (injonction de payer européenne); наказ про вчинення дії (injonction de faire) ${ }^{4}$.

Ст. 1405 Цивільного процесуального кодексу Франції (далі - ЦПК Франції) передбачає, що стягнення заборгованості в порядку подання заяви про видачу судового наказу можливе в таких випадках: а) право вимоги грунтується на договорі чи випливає з установленого нормативним актом зобов'язання та становить чітко визначену суму, зокрема, коли це штрафні санкції; б) зобов'язання випливає з вексельного обігу у визначених законом випадках або із прийняття уступки права вимоги, що передбачає спрощений порядок кредитування підприємств, відповідно до законодавства 5 .

У Цивільному процесуальному уложенні Німеччини (далі ЦПУНімеччини)наказнепровадженняіменуєтьсяMahnverfahren. Згідно з 688 ЦПУ Німеччини, на вимогу, предметом якої є сплата певних грошових коштів, за заявою заявника видається судовий наказ про сплату. Водночас стягнення в порядку наказного провадження не здійснюється за таких умов: а) щодо вимог суб'єкта підприємницької діяльності за договорами, передбаченими в §§ 491-508 Цивільного уложення Німеччини (договори споживчого кредитування та договори 3 розстрочкою платежу), якщо відповідно до Цивільного уложення Німеччини встановлена на момент укладення договору річна процентна ставка перевищує базову процентну ставку, встановлену законом, більше ніж на 12\%; б) якщо заявлена вимога залежить від ще не виконаного зустрічного виконання; в) якщо вручення судового наказу здійснюється в порядку публічного сповіщення ${ }^{6}$.

Отже, як загальноєвропейське, так і національне законодавство окремих держав характеризується широким колом підстав, за якими може бути видано судовий наказ із вираженою тенденцією не описувати вимоги, за якими може бути видано судовий наказ, а із вказівкою на правовідносини, у яких наказне провадження застосовуватися не може.

4 Français Code de procédure civile. URL: https://www.legifrance.gouv.fr/affichCode.do?cidTexte=LEGITEXT000006070716 (дата звернення: 13.02.2020).

5 Français Code de procédure civile. URL: https://www.legifrance.gouv.fr/affichCode.do?cidTexte=LEGITEXT000006070716 (дата звернення: 13.02.2020).

6 Deutsch Zivilprozessordnung. URL: https://www.gesetze-im-internet.de/bundesrecht/zpo/ gesamt.pdf (дата звернення: 13.02.2020). 
Український законодавець пішов іншим шляхом, чітко визначив вимоги, за якими може бути видано судовий наказ. У науковій літературі, зокрема російській, де наказне провадження врегульовано подібно до українського законодавства, висловлюється думка, що до наказного провадження можна було б віднести будь-які обгрунтовані вимоги, грошовий вираз яких не перевищує певного розміру, наприклад, 100 мінімальних розмірів оплати праці, а також нескладні у плані правової оцінки вимоги, але такі, що потребують негайного вирішення, наприклад виселення із самовільно зайнятого жилого приміщення ${ }^{7}$. Уважаємо, що настільки кардинальне розширення наказного провадження є не зовсім доречним, оскільки, зважаючи на питому вагу справ наказного провадження, даний інститут в основному справляється $з$ функціями, які на нього були покладені, окрім цього, таке правове регулювання дозволяє досконаліше врегулювати наказне провадження $з$ окремих вимог (про стягнення аліментів на дитину). Водночас питання розширення сфери застосування наказного провадження, безумовно, є актуальним, але виключно шляхом збільшення вимог, за яким може видаватися судовий наказ.

Як уже зазначалось вище, чинне законодавство України передбачає вичерпний перелік вимог, за якими може бути видано судовий наказ. Відповідно до ст. 161 ЦПК України, судовий наказ може бути видано, якщо:

1) заявлено вимогу про стягнення нарахованої, але не виплаченої працівникові суми заробітної плати та середнього заробітку за час затримки розрахунку. Дана вимога посідає досить значне місце серед справ наказного провадження: у 2018 р. було видано 6,19\% судових наказів саме 3 даної категорії справ ${ }^{8}$. Безумовно, можливість стягнення нарахованої, але не виплаченої зарплати в порядку наказного провадження суттєво покращує можливість захисту фізичними особами своїх порушених трудових прав. Водночас на практиці часто трапляється ситуація, коли вимагають стягнути нараховані, але не виплачені інші грошові суми (вихідна допомога, підйомна допомога тощо). На даний момент такі справи можуть розглядатись тільки в порядку позовного провадження. Хоча по своїй юридичній природі вони фактично нічим не відрізняються від вимог про

\footnotetext{
7 Решетняк В., Черных И. Заочное производство и судебный приказ в гражданском процессе. Москва : Юридическое бюро «Городец», 1997. С. 57.

8 Форма № 1-ц. Звіт судів першої інстанції про розгляд справ у порядку цивільного судочинства за 2018 p. URL: https://court.gov.ua/userfiles/media/media/1c_2018.xlsx (дата звернення: 13.02.2020).
} 
стягнення нарахованої, але не виплаченої зарплати, і неможливість вирішення даних вимог у порядку наказного провадження тільки ускладнює захист фізичними особами своїх прав. Для усунення даного недоліку, на нашу думку, п. 1 ст. 161 ЦПК України варто змінити і викласти в такій редакції: «Заявлено вимогу про стягнення нарахованої, але не виплаченої працівникові суми заробітної плати, середнього заробітку за час затримки розрахунку та інших платежів, передбачених законодавством про працю». Під іншими платежами, передбаченими законодавством про працю, варто розуміти грошові суми, які повинні бути виплачені саме працівникові, а не звичайній фізичній особі;

2) заявлено вимогу про компенсацію витрат на проведення розшуку відповідача, боржника, дитини або транспортних засобів боржника. Аналізуючи вищевказану вимогу для видачі судового наказу, варто зазначити, що на практиці судові накази на такій підставі видаються надзвичайно рідко. Так, у 2018 р. було видано тільки 2 судові накази даної категорії. На нашу думку, видача судових наказів за цією вимогою і надалі буде надзвичайно рідкісною. Це пов'язано з певними теоретичними та практичними проблемами спеціального законодавства щодо фінансування з боку держави проведення органами внутрішніх справ розшуку ${ }^{10}$. На практиці можуть виникати питання, пов'язані з тим, наскільки ефективними та відповідними будуть засоби, застосовані заінтересованими особами на проведення розшуку. Загалом варто зазначити, що, як показує судова практика, наявність даної підстави для видачі судового наказу є неефективною. 3 огляду на це вважаємо за доцільне скасувати таку вимогу для видачі судового наказу;

3) заявлено вимогу про стягнення аліментів у розмірі: на одну дитину-однієїчверті, на двох дітей-однієї третини, на трьох і більие дітей - половини заробітку (доходу) платника аліментів, але не більие десяти прожиткових мінімумів на дитину відповідного віку на кожну дитину, якщу ия вимога не пов 'язана з установленням чи оспорюванням батьківства (материнства) та необхідністю залучення інших заінтересованих осіб. Дана вимога посідає провідне місце серед справ наказного провадження: у 2018 р. було видано 18,94\% судових наказів саме

\footnotetext{
9 Форма № 1-ц. Звіт судів першої інстанції про розгляд справ у порядку цивільного судочинства за 2018 p. URL: https://court.gov.ua/userfiles/media/media/1c_2018.xlsx (дата звернення: 13.02.2020).

10 Луспеник Д. Судовий наказ у цивільному судочинстві. Юридичний журнал. 2007. № 2. C. 114 .
} 
цієї категорії ${ }^{11}$, що додатково підтверджує ефективність ії застосування для захисту прав та інтересів заінтересованих осіб;

4) заявлено вимогу про стягнення аліментів на дитину у твердій грошовій сумі в розмірі 50\% прожиткового мінімуму для дитини відповідного віку, якшо ияя вимога не пов'язана із встановленням чи оспорюванням батьківства (материнства) та необхідністю залучення інших заінтересованих осіб. За цією категорією справ у 2018 р. було видано $5 \%$ судових наказів ${ }^{12}$, наявність такої вимоги, безумовно, виправдана за неможливості чи недоцільності застосування попередньої вимоги;

5) заявлено вимогу про повернення вартості товару неналежної якості, якщо є рішення суду, яке набрало чинності, про встановлення факту продажу товару неналежної якості, ухвалене на користь невизначеного кола споживачів. Варто зазначити, що вищевказана вимога має дуже незначне місце серед справ наказного провадження: у 2018 р. було видано тільки 8 судових наказів щодо цієї категорії справ ${ }^{13}$. Незважаючи на незначну ефективність даної норми, загалом варто позитивно оцінити розширення можливості захисту своїх прав споживачами. Для широкого використання даної підстави видачі судового наказу потрібно вдосконалити законодавство про захист прав споживачів, особливо у сфері можливості встановлення судами на користь невизначеного кола споживачів факту продажу товару неналежної якості;

6) заявлено вимогу про стягнення заборгованості за оплату житлово-комунальних послуг, телекомунікаційних послуг, послуг телебачення та радіомовлення з урахуванням індексу інфлячії та 3\% річних, нарахованих заявником на суму заборгованості. Вищевказана вимога посідає перше місце серед справ наказного провадження: у 2018 р. було видано $65,02 \%$ судових наказів саме за даною категорією справ ${ }^{14}$. Аналіз даної вимоги доцільно провести разом із наступною вимогою;

\footnotetext{
11 Форма № 1-ц. Звіт судів першої інстанції про розгляд справ у порядку цивільного судочинства за 2018 p. URL: https://court.gov.ua/userfiles/media/media/1c_2018.xlsx (дата звернення: 13.02.2020).

12 Форма № 1-ц. Звіт судів першої інстанції про розгляд справ у порядку цивільного судочинства за 2018 p. URL: https://court.gov.ua/userfiles/media/media/1c_2018.xlsx (дата звернення: 13.02.2020).

13 Форма № 1-ц. Звіт судів першої інстанції про розгляд справ у порядку цивільного судочинства за 2018 p. URL: https://court.gov.ua/userfiles/media/media/1c_2018.xlsx (дата звернення: 13.02.2020).

14 Форма № 1-ц. Звіт судів першої інстанції про розгляд справ у порядку цивільного судочинства за 2018 p. URL: https://court.gov.ua/userfiles/media/media/1c_2018.xlsx (дата звернення: 13.02 .2020$)$.
} 
7) заявлено вимогу до юридичної особи або фізичної особипідприємия про стягнення заборгованості за договором (іншим, ніж про надання житлово-комунальних послуг, телекомунікаційних послуг, послуг телебачення та радіомовлення), укладеним у письмовій (зокрема, електронній) формі, якщо сума вимоги не перевищує ста розмірів прожиткового мінімуму для працездатних осіб. Дана категорія справ займає досить незначне місце серед справ наказного провадження: у 2018 р. було видано $0,36 \%$ судових наказів за цією вимогою ${ }^{15}$.

Аналізуючи дві останні вимоги, варто зазначити, що до змін у ЦПК України від 7 липня 2010 р. можна було видавати судові накази, якщо заявлено вимогу, що грунтується на правочині, вчиненому в письмовій формі. До 2010 р. дана категорія справ суттєво переважала в наказному провадженні. Так, у 2009 р. за такою вимогою було видано 86,41\% (311 886) судових наказів. Скасовано у 2009 р. було тільки $7,01 \%$ судових наказів даної категорії ${ }^{16}$. Це свідчить про високу якість виданих судових наказів вищевказаної категорії. Більшість справ за даною вимогою становили справи щодо видачі судових наказів про стягнення грошових коштів за такими категоріями: а) заяви банків про стягнення $з$ фізичних осіб боргу за кредитними договорами; б) заяви фізичних осіб щодо наданої ними іншим особам у позику грошових коштів за письмовим договором (зазвичай позики); в) заяви щодо стягнення заборгованості за надані комунальні послуги, електропостачання, газопостачання, послуги зв'язку, оренду землі тощо ${ }^{17}$.

Отже, сьогодні, порівняно з редакцією ЦПК України, яка діяла до 2010 р., не можуть розглядатися в порядку наказного провадження заяви банків про стягнення з фізичних осіб боргу за кредитними договорами, а також заяви фізичних осіб щодо наданих ними іншим фізичним особам у позику грошових коштів за письмовим договором (зазвичай позики). Уважаємо, що обмеження, наявні в чинному законодавстві, за видами договорів (про надання житлово-комунальних послуг, телекомунікаційних послуг, послуг телебачення та радіомовлення) та за суб'єктним складом за іншими договорами (боржником може бути тільки

15 Форма № 1-ц. Звіт судів першої інстанції про розгляд справ у порядку цивільного судочинства за 2018 p. URL: https://court.gov.ua/userfiles/media/media/1c_2018.xlsx (дата звернення: 13.02.2020).

16 Форма № 2-ц. Звіт судів першої інстанції про розгляд у порядку цивільного судочинства за 2009 p. URL: https://court.gov.ua/userfiles/2-C-2009.xls (дата звернення: 13.02.2020).

17 Узагальнення Верховного Суду України. Практика розгляду судами цивільних справ у наказному провадженні від 1 липня 2007 p. URL: https://docs.dtkt.ua/download/ pdf/1077.1850.1 (дата звернення: 13.02.2020). 
юридична особа або фізична особа-підприємець) є невиправданим і таким, що порушує рівність учасників цивільного процесу.

Варто зазначити, що українське законодавство передбачає можливість стягнення заборгованості в безспірному порядку на підставі виконавчих написів нотаріусів за нотаріально посвідченими договорами, кредитними договорами, іпотечними договорами та 3 інших підстав (постанова Кабінету Міністрів України «Про затвердження переліку документів, за якими стягнення заборгованості провадиться у безспірному порядку на підставі виконавчих написів нотаріусів» від 29 червня 1999 р. № 1172). Якщо ж учасник, чиї права порушені, захоче звернутися до суду для захисту своїх прав та інтересів, він не зможе зробити це в порядку наказного провадження. Тому доцільно замість вимог, визначених у п.п. 3 і 7 ч. 1 ст. 161 ЦПК України, визначити одну вимогу для видачі судового наказу: «Заявлено вимогу про стягнення заборгованості за договором, укладеним у письмовій (зокрема, електронній) формі з урахуванням індексу інфляиії та 3\% річних, нарахованих заявником на суму заборгованості, якщо сума вимоги не перевищує ста розмірів прожсткового мінімуму для пращездатних осіб», як це зроблено у ГПК України.

Проблема визначення вимог, за якими видається судовий наказ, є глобальною. Розвиток суспільних правовідносин, а також аналіз практики показують, що фактично безспірних справ, які розглядаються в позовному провадженні, у зв'язку з тим, що законодавець не включив їх у наказне провадження, набагато більше. Наприклад, доцільним є включення до наказного провадження такої вимоги, як компенсування матеріальної шкоди, завданої злочином або адміністративним проступком, коли вина особи встановлена рішенням компетентного органу, а розмір збитків підтверджується рішенням суду або в інший спосіб, визначений законом. Як свідчить статистика, у 2018 р. тільки за вимогою про компенсування шкоди фізичній особі, яка потерпіла від кримінального правопорушення, було розглянуто в порядку цивільного судочинства 2071 справу $^{18}$. Віднесення даної категорії до наказного провадження сприятиме ефективнішому захисту прав та інтересів заінтересованих осіб.

Отже, підтримуючи загалом позицію нашого законодавця про необхідність чіткого визначення вимог, за якими може бути видано судовий

\footnotetext{
18 Форма № 1-ц. Звіт судів першої інстанції про розгляд справ у порядку цивільного судочинства за 2018 p. URL: https://court.gov.ua/userfiles/media/media/1c_2018.xlsx (дата звернення: 13.02.2020).
} 
наказ, уважаємо, що для забезпечення більшої доступності, швидкості й ефективності судового розгляду необхідно розширити сферу застосування наказного провадження, виклавши ч. 1 ст. 161 ЦПК України в такій редакції:

1. Судовий наказ може бути видано, якщо:

1) заявлено вимогу про стягнення заборгованості за договором, укладеним у письмовій (зокрема, електронній) формі з урахуванням індексу інфляиії та 3\% річних, нарахованих заявником на суму заборгованості, якщуо сума вимоги не перевищує ста розмірів прожиткового мінімуму для працездатних осіб;

2) заявлено вимогу про стягнення нарахованої, але не виплаченої працівникові суми заробітної плати, середнього заробітку за час затримки розрахунку та інших платежів, передбачених законодавством про працую;

3) заявлено вимогу про відикодування матеріальної икоди, завданої злочином або адміністративним проступком, коли вина особи встановлена рішенням суду, а розмір збитків підтверджсуться рішенням суду або в іниий спосіб, визначений законом;

4) заявлено вимогу про стягнення аліментів у розмірі: на одну дитину - однієї чверті, на двох дітей - однієї третини, на трьох і більше дітей - половини заробітку (доходу) платника аліментів, але не більше десяти прожиткових мінімумів на дитину відповідного віку на кожну дитину, якщо ця вимога не пов'язана із встановленням чи оспорюванням батьківства (материнства) та необхідністю залучення інших заінтересованих осіб;

5) заявлено вимогу про стягнення аліментів на дитину у твердій грошовій сумі в розмірі 50\% прожиткового мінімуму для дитини відповідного віку, якщо ця вимога не пов' язана із встановленням чи оспорюванням батьківства (материнства) та необхідністю залучення інших заінтересованих осіб;

6) заявлено вимогу про повернення вартості товару неналежної якості, якщо є рішення суду, яке набрало чинності, про встановлення факту продажу товару неналежної якості, ухвалене на користь невизначеного кола споживачів.

Таке розширення сфери застосування наказного провадження дозволить майже повною мірою гармонізувати законодавство України та Європейського Союзу у сфері наказного провадження в цивільному процесі та приведе до збільшення частки справ наказного провадження в цивільному судочинстві до 30-35\%. 


\section{2. Розгляд заяви про видачу судового наказу \\ та скасування судового наказу}

Процедура наказного провадження, згідно з Регламентом «Про введення Європейського наказного провадження», складається 3 таких стадій: а) вивчення заяви про видачу Свропейського виконавчого листа й ухвалення рішення щодо заяви; б) подання заперечення на Європейський виконавчий лист і перевід справи в загальне цивільне судочинство; в) примусове виконання Свропейського виконавчого листа.

На першій стадії відбувається вивчення заяви про видачу Свропейського виконавчого листа на предмет відповідності сфери застосування, транскордонного характеру справи, вимогам щодо Європейського виконавчого листа, підсудності та змісту заяви про видачу Європейського виконавчого листа. У заяві про видачу Європейського виконавчого листа вказуються: найменування й адреси сторін; сума позову, включаючи процентні ставки та неустойку; період розрахунку та розмір процентної ставки; підстави подачі заяви, включаючи обставини справи; опис доказів; обгрунтування підсудності та транскордонного характеру справи. Подання в заяві неправдивої інформації може призвести до санкцій, що передбачені національним законодавством. Регламентом передбачено можливість подання даної заяви в електронній формі, якщо це допускає національне законодавство. Якщо не були дотримані вимоги щодо змісту заяви, суд зобов'язаний надати заявнику можливість доповнити, уточнити або змінити заяву протягом розумного строку.

Регламент передбачає такі можливості: відхилити заяву чи видати Європейський виконавчий лист. Суд може відхилити заяву тільки в таких випадках: а) заява не відповідає вимогам, передбаченим цим Регламентом; б) заява завідомо необгрунтована; в) заяву не було доповнено, уточнено або змінено протягом строку, встановленого судом.

Якщо заявник дотримався всіх вимог, визначених Регламентом, суд зобов'язаний у строк не пізніше 30 днів видати Європейський виконавчий лист, у якому відповідачу надається альтернатива або задовольнити вимоги позивача, або протягом 30 днів із моменту отримання подати заперечення. Відповідачу роз'яснюється, що: а) виконавчий лист виданий виключно на підставі інформації, поданої позивачем, яка не перевірялася судом; б) виконавчий лист набуває чинності, якщо не були подані заперечення; в) у разі подачі заперечень судовий розгляд буде проходити в загальному порядку, якщо позивач окремо не заявив про припинення судового розгляду на даному етапі. 
Наступна стадія наказного провадження охоплює заперечення на Свропейський виконавчий лист. Відповідач у своїй заяві про незгоду з позовом не зобов'язаний зазначати причини такої незгоди. За своєчасної подачі заперечень відбувається перевід справи в загальне цивільне судочинство відповідно до національного законодавства, про це повинен бути повідомлений позивач.

І заключною стадією є примусове виконання Свропейського виконавчого листа ${ }^{19}$.

ЦПК Франції передбачає, що в заяві про видачу судового наказу повинно бути вказано: індивідуалізуючі дані кредитора та дебітора; точна вказівка на суму, що стягується, з детальним переліком складників права вимоги, а також підстава останньої. До заяви додаються документи на іiі підтвердження. У ній кредитор може зазначити, що в разі заперечень справа має невідкладно бути передана в суд для розгляду в загальному порядку.

Суд, дослідивши подані документи та вирішивши, що вимога є обгрунтованою повністю чи частково, виносить ухвалу, що містить розпорядження про сплату. Якщо суд відхиляє заяву або задовольняє частково, його ухвала не може бути оскаржена кредитором, однак останній може звернутися з вимогою в загальному (позовному) порядку.

За ініціативою кредитора завірені копії його заяви й ухвали суду надсилаються в порядку судового повідомлення кожному з боржників. Ухвала, що містить розпорядження про сплату, уважається такою, що не відбулась, якщо протягом шести місяців про неї не здійснено судове повідомлення, а також якщо протягом одного місяця із дня закінчення строку, встановленого для подачі боржником заперечень, кредитор не звернувся із клопотанням про виконавчий напис на даній ухвалі. В акті судового повідомлення про винесену ухвалу, що містить розпорядження про сплату, має бути зазначено або обов'язок сплатити кредитору визначену суму, або подати свої заперечення на заяву кредитора, а також строк, протягом якого можна подати заперечення (один місяць). Для розгляду заперечень боржника в судове засідання викликаються всі учасники процесу. У разі неявки всіх учасників суд виносить постанову про припинення провадження, що призводить до визнання ухвали, що містить розпорядження про сплату, такою, що

\footnotetext{
19 Regulation (EC) № 1896/2006 of the European Parliament and of the Council of 12 December 2006 creating a European order for payment procedure. URL: http://eur-lex.europa.eu/legal-content/EN/TXT/?uri=celex:32006R1896 (дата звернення: 13.02.2020).
} 
не відбулась. Що стосується заперечень боржника, то суд розглядає ïх по суті разом із вимогами кредитора та виносить рішення, яке замінює ухвалу, що містить розпорядження про сплату, дане рішення може бути оскаржене в загальному порядку 20.

У ЦПУ Німеччини зазначено, що зміст заяви про видачу судового наказу повинен містити: а) найменування сторін, їхніх представників; б) найменування суду; в) основну та додаткову вимоги з конкретною вказівкою на виконання за кожною з них; г) вказівку, що вимога не залежить від зустрічного виконання; г) найменування суду, якому підвідомче дане провадження.

Заява про видачу судового наказу відхиляється, якщо за даною вимогою не може бути виданий судовий наказ, справа не підсудна даному суду, заява не відповідає змісту, визначеному в законі, проте перед відхиленням повинен бути заслуханий заявник. В інших випадках суд зобов'язаний видати судовий наказ, який має містити: а) дані щодо заяви про видачу судового наказу; б) вказівку, що суд не перевіряв обгрунтованості заявлених вимог; в) вимогу сплатити заявлену суму протягом двох тижнів; г) вказівку, що може бути видана ухвала про примусове виконання судового наказу тощо. Судовий наказ подається боржнику, який може подати свої заперечення до винесення ухвали про примусове виконання судового наказу. § 696 Цивільного уложення Німеччини передбачає, що коли заперечення подається своєчасно, а одна зі сторін вимагає позовного провадження, то суд, який видав судовий наказ, передає справу для розгляду в порядку позовного провадження. Якщо судовий наказ не був опротестований, а протягом шести місяців не подається заява про винесення ухвали про примусове виконання судового наказу, дія судового наказу припиняється.

Якщо заява направлена на видачу судового наказу на документ, вексель чи чек, то судовий наказ іменується відповідно документальним, вексельним або чековим наказом. У разі видачі такого судового наказу діють особливі правила його примусового виконання, а також особливості розгляду в позовному провадженні за оскарження боржником ${ }^{21}$.

Отже, законодавче регулювання розгляду заяви про видачу судового наказу та його скасування в Німеччині та Франції чітко вписується у правові моделі даного інституту - доказову та бездоказову, про ознаки яких

${ }^{20}$ Français Code de procédure civile. URL: https://www.legifrance.gouv.fr/affichCode.do?cidTexte=LEGITEXT000006070716 (дата звернення: 13.02.2020).

${ }^{21}$ Deutsch Zivilprozessordnung. URL: https://www.gesetze-im-internet.de/bundesrecht/zpo/ gesamt.pdf (дата звернення: 13.02.2020). 
ішлося вище. Аналіз Регламенту «Про введення Свропейського наказного провадження» дозволяє зробити висновок, що для загальноєвропейського законодавства характерна бездоказова модель правового регулювання наказного провадження. Водночас варто підкреслити наявність як в бездоказовій моделі окремих елементів доказової моделі (перед відхиленням заяви про видачу судового наказу повинен бути заслуханий заявник - § 691 ЦПУ Німеччини; суд може відхилити заяву про видачу Свропейського виконавчого листа, якщо заява завідомо необгрунтована, - ст. 11 Регламенту «Про введення Свропейського наказного провадження»), так і в доказовій моделі окремих елементів бездоказової моделі (судовий наказ видається тільки на основі доказів, поданих кредитором, - ст. 1409 ЦПК Франціï).

Аналіз наказного провадження у ЦПК України дозволяс однозначно віднести даний інститут до бездоказової моделі правового регулювання. Водночас вітчизняне законодавство характеризується значною деталізацією окремих положень, спрямованих, з одного боку, на забезпечення доступності, швидкості й ефективності судового розгляду, а з іншого - на недопущення можливості зловживання стягувачем своїми правами, ефективний захист прав боржника.

Наказне провадження в Україні складається 3 кількох стадій: розгляд заяви та видача судового наказу; скасування судового наказу; виконання судового наказу. Відповідно до ст. 167 ЦПК України, суд розглядає заяву про видачу судового наказу протягом п’яти днів. Розгляд проводиться без судового засідання і повідомлення заявника та боржника. За результатами розгляду заяви про видачу судового наказу суд видає судовий наказ або постановляє ухвалу про відмову у видачі судового наказу.

Чинне законодавство визначає чіткий перелік підстав, коли суд може відмовити у видачі судового наказу. Так, згідно зі ст. 165 ЦПК України, суддя відмовляє у видачі судового наказу, якщо: а) заява подана $з$ порушеннями форми та змісту, визначених законом; б) заяву подано особою, яка не має процесуальної дієздатності, не підписано або підписано особою, яка не має права iї підписувати, або особою, посадове становище якої не вказано; в) заявлено вимогу, яка не відповідає вимогам, встановленим законом; г) наявні загальні обставини, які перешкоджають відкриттю провадження у справі (ч. 1 ст. 186 ЦПК України); г) з моменту виникнення права вимоги пройшов строк, який перевищує позовну давність, встановлену законом для такої вимоги, або пройшов строк, встановлений законом для пред’явлення позову в суд за такою 
вимогою; д) судом раніше виданий судовий наказ за тими самими вимогами, за якими заявник просить видати судовий наказ; е) судом раніше відмовлено у видачі судового наказу з підстав, які перешкоджають повторному зверненню до суду (п. п. 3-6 ч. 1 ст. 165 ЦПК України); є) із поданої заяви не вбачається виникнення або порушення права грошової вимоги, за якою заявником подано заяву про видачу судового наказу; ж) заяву подано з порушенням правил підсудності; з) якщо отримана судом інформація не дає можливості встановити зареєстроване у встановленому законом порядку місце проживання (перебування) фізичної особи-боржника. У всіх інших випадках суд зобов’язаний видати судовий наказ.

У судовому наказі зазначаються: а) дата видачі наказу; б) найменування суду, прізвище й ініціали судді, який видав судовий наказ; в) повне найменування стягувача і боржника, їх місцезнаходження або місце проживання чи перебування, ідентифікаційний код юридичної особи / реєстраційний номер облікової картки платника податків (для фізичних осіб), а також інші дані, якщо вони відомі суду, які ідентифікують стягувача та боржника; г) посилання на закон, на підставі якого підлягають задоволенню заявлені вимоги; г) сума грошових коштів, які підлягають стягненню; д) сума судових витрат, що сплачена заявником і підлягає стягненню на його користь з боржника; е) повідомлення про те, що під час розгляду вимог у порядку наказного провадження та видачі судового наказу суд не розглядає обгрунтованість заявлених стягувачем вимог по суті; є) відомості про порядок та строки подання заяви про скасування судового наказу; ж) дата набрання судовим наказом чинності; з) строк пред'явлення судового наказу до виконання; и) дата видачі судового наказу стягувачу. Після видачі судового наказу суд не пізніше наступного дня надсилає його копію боржникові.

Боржник має право протягом п’ятнадцяти днів із дня вручення копії судового наказу та доданих до неї документів подати заяву про його скасування до суду, який його видав, крім випадків видачі судового наказу про стягнення аліментів (п. п. 4, 5 ч. 1 ст. 161 ЦПК України). В останніх випадках закон допускає можливість звернутися до суду з позовом про зменшення розміру аліментів.

Заява про скасування судового наказу подається в суд у письмовій формі та повинна містити: а) найменування суду; б) повне найменування стягувача i боржника, їх місцезнаходження або місце проживання чи перебування, ідентифікаційний код юридичної особи / реєстраційний номер облікової картки платника податків 
(для фізичних осіб); в) наказ, що оспорюється; г) зазначення повною або часткової необгрунтованості вимог стягувача.

У ст. 171 ЦПК України передбачено, що за відсутності підстав для повернення заяви про скасування судового наказу суддя не пізніше двох днів після ії подання постановляє ухвалу про скасування судового наказу, в якій роз'яснює заявнику (стягувачу) його право звернутися до суду з тими самими вимогами в порядку спрощеного позовного провадження. Водночас закон передбачає, що єдиною підставою для повернення заяви про скасування судового наказу є подання заяви 3 порушенням строків, встановлених для скасування судового наказу (ч. 2 ст. 171 ЦПК України).

У разі ненадходження до суду заяви від боржника про скасування судового наказу протягом п'яти днів після закінчення строку для іiі подання судовий наказ набирає чинності, крім випадків видачі судового наказу за вимогами про стягнення аліментів на дитину, коли судовий наказ набирає чинності в день його видачі.

Також вартозазначити, що за клопотанням заінтересованих осіб суд може внести виправлення до судового наказу, відстрочити або розстрочити виконання судового наказу чи визнати його таким, що не підлягає виконанню (ст. 173 ЦПК України).

Законом чітко визначено, що судовий наказ оскарженню в апеляційному порядку не підлягає, допускається тільки апеляційне оскарження ухвали про відмову у видачі судового наказу. У касаційному порядку не можуть оскаржуватися ні судові накази, ні ухвали про відмову у видачі судового наказу.

Що ж до перегляду за нововиявленими або виключними обставинами, то закон допускає тільки перегляд за нововиявленими обставинами судових наказів за вимогами про стягнення аліментів на дитину. У всіх інших випадках перегляд справ наказного провадження за нововиявленими або виключними обставинами не допускається.

Фактично судовий наказ може бути скасований тільки в порядку, передбаченому р. II ЦПК України «Наказне провадження», за винятком справ за вимогами про стягнення аліментів на дитину, які не підлягають скасуванню.

Як бачимо, порядок розгляду заяви та видачі судового наказу за українським законодавством цілком узгоджується з бездоказовою моделлю правового регулювання наказного провадження, оскільки єдиною підставою для відмови у скасуванні судового наказу $є$ подання заяви про скасування судового наказу з порушенням строків, встановлених 
законом. Зауважимо значну деталізацію підстав для відмови у видачі судового наказу, однак вважаємо це виправданим, з огляду на необхідність мінімізувати можливість зловживання своїми правами з боку стягувача та належного захисту прав боржника. Окрім цього, вітчизняне законодавство врегульовує особливості наказного провадження за вимогами про стягнення аліментів на дитину, що дозволяє ефективніше захистити права й інтереси заінтересованих осіб.

\section{ВИСНОВКИ}

Підсумовуючи вищесказане, варто зазначити, що законодавство України у сфері наказного провадження значною мірою гармонізоване iз законодавством Свропейського Союзу. Вітчизняний законодавець обрав бездоказову модель наказного провадження, що є виправданим з огляду на можливість забезпечення доступності, швидкості й ефективності судового розгляду.

До особливостей інституту наказного провадження в цивільному процесі України варто віднести такі: а) вичерпний перелік вимог, за якими може бути видано судовий наказ; б) не розглядається обгрунтованість заявлених стягувачем вимог по суті; в) розширений перелік підстав для відмови у видачі судового наказу, спрямований на недопущення зловживання заявником своїми правами; г) формальна процедура скасування судового наказу (єдиною підставою для повернення заяви про скасування судового наказу є подання заяви 3 порушенням строків, встановлених законом), спрямована на захист прав боржника; г) встановлення особливостей наказного провадження за вимогами про стягнення аліментів на дитину.

Позитивно, загалом, оцінюємо правове регулювання наказного провадження в Україні, уважаємо за необхідне розширити сферу застосування наказного провадження. Зокрема, передбачити можливість видачі судового наказу, якщо заявлено вимогу про стягнення заборгованості за будь-яким договором, укладеним у письмовій (зокрема, електронній) формі, якщо сума вимоги не перевищує ста розмірів прожиткового мінімуму для працездатних осіб, а також якщо заявлено вимогу про відшкодування матеріальних збитків, завданих злочином або адміністративним проступком, коли вина особи встановлена рішенням суду, а розмір збитків підтверджується рішенням суду або в інший спосіб, визначений законом.

Таке розширення сфери застосування наказного провадження сприятиме забезпеченню більшої доступності, швидкості й ефективності 
судового розгляду, а також збільшенню частки справ наказного провадження в цивільному судочинстві до $30-35 \%$.

\section{АНОТАЦІЯ}

Дослідження присвячене питанням гармонізації законодавства України та Європейського Союзу у сфері наказного провадження в цивільному процесі. Аналіз інституту наказного провадження в Цивільному процесуальному уложенні Німеччини, Цивільному процесуальному кодексі Франції та Регламенті «Про введення Свропейського наказного провадження» дозволив виявити шляхи модернізації вітчизняного законодавства в даній сфері. Дослідження наказного провадження в Цивільному процесуальному кодексі України показує, що правове регулювання даного інституту належить до бездоказової моделі. Водночас наказне провадження в Україні характеризується низкою специфічних ознак. Особливості правового регулювання даного інституту в Цивільному процесуальному кодексі України спрямовані, з одного боку, на забезпечення доступності, швидкості й ефективності судового розгляду для заявника, а із другого - на недопущення зловживання заявником своїми правами та на захист прав боржника. Порівняльний аналіз наказного провадження у країнах Європейського Союзу й України дозволяє зробити висновок про необхідність розширення сфери застосування наказного провадження. Внесення змін до частини 1 статті 161 Цивільного процесуального кодексі України забезпечить більшу доступність, швидкість і ефективність судового розгляду, а також збільшить частку справ наказного провадження в цивільному судочинстві до 30-35\%.

\section{ЛІТЕРАТУРА}

1. Крымский Д. Упрощенные производства в гражданском процессе зарубежных стран : автореф. дис. ... канд. юрид. наук: 12.00.15. Москва, 2011. $26 \mathrm{c}$.

2. Луспеник Д. Судовий наказ у цивільному судочинстві. Юридичний журнал. 2007. № 2. С. 111-119.

3. Решетняк В., Черных И. Заочное производство и судебный приказ в гражданском процессе. Москва: Юридическое бюро «Городец», 1997. $80 \mathrm{c}$.

4. Узагальнення Верховного Суду України. Практика розгляду судами цивільних справ у наказному провадженні від 1 липня 2007 p. URL: https://docs.dtkt.ua/download/pdf/1077.1850.1 (дата звернення: 13.02.2020). 
5. Форма № 1-ц. Звіт судів першої інстанції про розгляд справ у порядку цивільного судочинства за 2018 p. URL: https:/court.gov.ua/ userfiles/media/media/1c_2018.xlsx (дата звернення: 13.02.2020).

6. Форма № 2-ц. Звіт судів першої інстанції про розгляд у порядку цивільного судочинства за 2009 p. URL: https:/court.gov.ua/ userfiles/2-C-2009.xls (дата звернення: 13.02.2020).

7. Deutsch Zivilprozessordnung. URL: https://www.gesetze-im-internet. de/bundesrecht/zpo/gesamt.pdf (дата звернення: 13.02.2020).

8. Français Code de procédure civile. URL: https://www.legifrance.gouv. fr/affichCode.do?cidTexte=LEGITEXT000006070716 (дата звернення: 13.02.2020).

9. Regulation (EC) № 1896/2006 of the European Parliament and of the Council of 12 December 2006 creating a European order for payment procedure. URL: http://eur-lex.europa.eu/legal-content/EN/ TXT/?uri=celex:32006R1896 (дата звернення: 13.02.2020).

\section{Information about author: \\ Velykoroda O. M., \\ Ph. D., Associate Professor,} Associate Professor of the Civil and Commercial Law and Process Department Ivano-Frankivsk Institute of Law of the National University "Odesa Law Academy" 13, Maksymovycha str., Ivano-Frankivsk, 76000, Ukraine DOI https://doi.org/10.30525/978-9934-588-43-3/1.28 